\title{
THE PREPARATION AND USAGE OF PUBLIC RESCUE UNITS COOPERATING WITH THE NATIONAL MEDICAL RESCUE SYSTEM TOWARDS ACTIONS TAKEN ON THE SPOT OF A DISASTER — AN ANALYSIS OF THE ISSUE BASED ON THE EXAMPLE OF WROCLAW AND LOWER SILESIA
}

\section{Pawel Piotr Gawlowski, Lukasz Iskrzycki}

Silesian Piastow Memorial Medical University, Wroclaw, Poland

\begin{abstract}
INTRODUCTION: A disaster is an occurrence requiring numerous emergency services being engaged in order to successfully bring help to the victims.

PURPOSE: The thesis describes Lower Silesia's public rescue units and the possibility of using them in the field of a disaster.

METHODS: The thesis descriptively presents a historical view of disasters, the Polish legal system that regulates the principles of operation on the field of the disaster and the disposal of the volunteer units. It also presents the legal requirements concerning the equipment of the above-mentioned units.

RESULTS: The volunteer rescue units present in Wroclaw and Lower Silesia are very well equipped while the rescuers are very highly trained. Their varied scope of operations enables the units' disposal both to natural and mechanical disasters. Continual rescue exercises allowed such procedures to gain a uniform character which improves the efficiency of the actions on the spot of the disaster.
\end{abstract}

CONCLUSIONS: The disposal of volunteer rescue units seems to be determined by long lasting actions due to the length of time needed to reach operational readiness.

KEY WORDS: disaster medicine, paramedics, volunteer rescue units, management of the disaster

Disaster Emerg Med J 2017; (2)1: 27-32

\section{INTRODUCTION}

Disasters are events which, since the down dawn of time, have caused fear and strongly influenced the affected societies. Although mythological tales report the destruction of Atlantis or a biblical deluge, later periods provide some more reliable reports of disasters. A good example is the story of the eruption of Vesuvius in the year 79 BCE which resulted in the death of 3,000 victims among the citizens of Pompeii, Herculaneum and Stabia. The probability of the occurrence of a disaster involving many casualties was low during these times due to the lower number of human conurbations, as well as the lack of developed technology possessing the energy which could cause such a disaster.

Modern times have brought more and more new threats related to the development of technology and interference in the natural world. Different phenomena and their scale do not permit one to form an unambiguous definition of a disaster. However, 
they do have some common features which make it possible to combine them into one distinguishable group. The first of these features is the lack of the possibility to define the place and time of the occurrence of a disaster, a factor which increases the ensuing shock and panic. A second feature is the type of a causative factor and the extent of the destruction that goes beyond one's possibility to provide efficient aid within a limited time. This fact often causes secondary disasters, e.g. the inability to bury the bodies quickly may cause an epidemiologic disaster. Currently, there is no single definition of a disaster which would be accepted by all institutions. The most common one is a definition formulated by the Red Cross and Federal Emergency Management Agency. It defines a disaster as follows: "A disaster is an event causing death, injuries and destruction of proprieties of such an intensity that the routinely taken actions aiming to limit its consequences are insufficient. It usually occurs suddenly and requires an immediate, coordinated action of many people and institutions". This definition is to a large extent oriented on the presence of casualties. However, we must remember that the biggest disasters both in our country and in neighbouring countries concerned events not involving a very big number of wounded persons, but events doing significant damage to the environment. From an epidemic point of view, "a disaster is a result of an important disturbance of the ecologic relations between a man and his environment, which occurs suddenly (e.g. the explosion of the nuclear power plant at Chernobyl) or bourgeons over a longer period of time (e.g. the flood in Poland in 1997 or a drought in 2011 when, all over Europe, the lowest waters levels for more than 100 years were registered), and which requires external or international help" [1].

\section{THE AREA OF POTENTIAL THREAT}

Wroclaw is the capital of Lower Silesia and covers an area of $292.82 \mathrm{~km}^{2}$ (Fig. 1). It is inhabited by 637,075 people which results in a population density of 2,176 persons per $\mathrm{km}^{2}$. One of the largest Polish rivers flows through Wroclaw, namely the Oder (Odra), which is a navigable and regulated river and has at the borders of the city, four big creeks. Within the limits of the city we can find a very large railway junction (for passengers and freight trains), an international airport, as well as a highly developed pub-

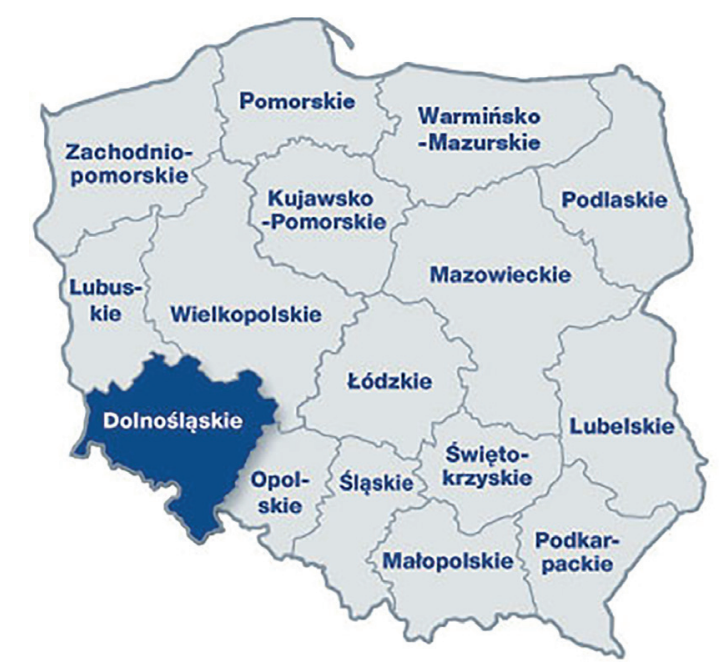

FIGURE 1. Location of Lower Silesia

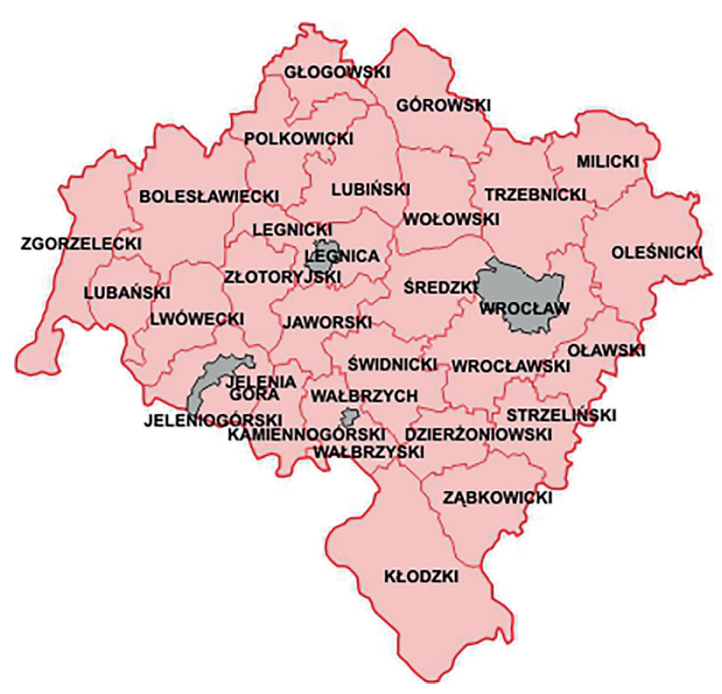

FIGURE 2. Counties of Lower Silesia Province

lic transport network (trams and buses). Moreover, some large communication junctions of fast roads and highways have been built recently. A number of industrial production facilities, which possess on their sites many chemical substances potentially dangerous for humans and the environment, are also located in the city. Wroclaw is also an agglomeration of courts, offices and other institutions which may be potential targets of a terroristic attack.

Lower Silesia province covers an area of $19,946.7 \mathrm{~km}^{2}$ and is located in the south-western part of Poland. It has 2,903,812 inhabitants which results in a population density of 145.6 persons per $\mathrm{km}^{2}$. The biggest cities in this region include Jelenia Gora, Walbrzych and Legnica (Fig. 2). The province of Lower Silesia borders Germany and the Czech Republic and is a transit province for both tourist and 
heavy-goods transport. The A8 and A4 highways have the highest levels of traffic. Moreover, heavy traffic is also observed in all other roads due the presence of industrial areas and tourist destinations. The Sudety mountain range also extends across Lower Silesia. There is a dense, highly developed fluvial system which has a rather poor flood protection. Many production plants produce some chemical agents which constitute a significant danger for the local population (e.g. PCC Rokita S.A. in Dolny Brzeg). In addition, many railway communication junctions are also located on this area. This above description both of the city and of the province shows that the potential dangers for a disaster to occur may be found in the natural environment (mountains, rivers), industry (production plants, dangerous agents), in heavy communication traffic (railway, passenger cars, trucks), as well as in the presence of some important public institutions in this region (offices, courts etc.) [2].

\section{THE LEGAL BASIS OF THE UNITS SUPPORTING THE NATIONAL MEDICAL RESCUE TEAM}

Until the National Medical Rescue Team law had been issued, the actions of the voluntary units supporting the professional services were not managed by any regulations in Polish law. These volunteer groups were organized by themselves and were not subjected to a unified procedure of evaluation of the competences of their members and quality of their equipment. The volunteer group usually showed up at the disaster site due to information intercepted on an emergency frequency or had signed a separate agreement with the rescue team acting in a given area. A breakthrough moment came during the dramatic events on the 26th of January 2006, when a construction disaster occurred on the area of the International Trade Fair in Katowice, killing 66 people and injuring 170 under the collapsed building. Although professional rescue units were called to the site, in the initial phase nobody could even estimate the number of injured people. After information was first released in the public media, volunteer units from all over Poland, as well as a search party from Germany, began to arrive at the disaster site. Due to the character of the region, coal-mine rescuers also joined the rescue operation [3]. At that time, the lack of any regulations or procedures allowed any rescue team to join the rescue operation, based on an verbal declaration of the competences of the rescuers and equipment. Only these events led to the creation of the National Medical Rescue Team Act, a law which regulates the functioning of the supporting units of the National Medical Rescue System [4].

A member of such a unit must be a rescuer. The act states that the person who claims to be a rescuer must have both the full legal capacity to do so and be in a condition of health appropriate for providing professional first aid. However, there are no regulations defining the range of medical exams and the exact form of official certificates. A rescuer must also be member of a cooperating unit and have completed a certified first aid course. The programme of this course is accepted by the province responsible for the place where the course is registered and conducted and which confirms the compatibility of the programme and its adherence with the current regulations as defined by the Minister of Health. These current regulations foresee that each person who completes a certified first aid course and who wishes to be appointed with the title of 'rescuer', will be able to perform activities related to the following: cardiopulmonary resuscitation; oxygen supply; the use of Automated External Defibrillator (AED); stopping haemorrhages and dressing wounds; immobilizing fractures and dislocations; providing thermal comfort; the implementation of anti-shock procedures; the evacuation of people in physical danger; psychological support; as well as medical segregation. The act regulates in detail the list of professional subjects who may cooperate with National Medical Rescue System. These are as follows: the units of the National Fire Department; the Volunteer Fire Department integrated into the National Rescue-Firefighting System, and those authorized based on other regulations, namely mountain and water rescue units, as well as some other subordinated units supervised by the Ministry of the Interior and the Ministry of National Defence. These rules have made it possible to include in the registry the following professional units working in Lower Silesia: VMES (Volunteer Mountain Emergency Service) - Karkonoska Group, VMES - Wałbrzysko-Kłodzka Group, Volunteer Water Emergency Service, the Sudety Border Guard Unit as well as units of the National Fire Department Services and Volunteer Fire Department Services. It is worth to mentioning that the law of August 18, 2011 regarding the safety and rescue service in the mountains and on the organized skiing-areas, as well as regarding people using areas 
of water, broaden the possibilities of the cooperation of medical rescuers within the units cooperating with the National Medical Rescue System. This law certifies that a medical rescuer may take part in medical rescue activities as defined by this law and by its ordinances. Currently, these units comprise 967 rescuers and 282 R1 groups. The additional equipment of these units include as follows: passenger cars; trucks and technical vehicles; buses; dump trucks; quad bikes; motorbikes; snow scooters; altitude, water and mountain rescue equipment; communication equipment compatible with units of the National Medical Rescue Services $[5,6]$. It is important that these regulations also define the cooperation of volunteer rescue units. These units must have a policy statement or law which oblige them to provide aid in cases of sudden danger to human health. These units must be entered by the province into the registry of the units cooperating with the National Medical Rescue System [7]. This is computer registry includes data concerning the following: the names and locations of the units concerned; the area of operation; the number of rescuers; equipment certification; the range of time of readiness; as well as contact telephone numbers. All of this information is referred to the Emergency Management Centre $[8,9]$. Currently, the Lower Silesia registry includes thirteen voluntary units, nine of whom are based in Wroclaw and whose training concerns medical, water and catastrophic rescue. The other similar units are based in Zlotoryja, Kamienna Gora, Pielgrzymka and Olesnica and whose rescue profile is comparable to those based in Wroclaw. Currently, four groups work actively in Lower Silesia. A description of these groups is presented in the next chapter [10].

\section{AN OUTLINE OF SELECTED VOLUNTEER UNITS SUPPORTING THE NATIONAL MEDICAL RESCUE SYSTEM}

\section{The Volunteer Fire Department Services - The Specialist Rescue Unit in Wroclaw (VFDS SRU)}

The VFDS SRU in Wroclaw mostly specializes in searching for people in natural and forested areas, as well as under building rubble. This unit numbers 31 people, 22 of whom have completed basic VFDS firefighter training. Moreover, 16 firefighters completed certified first aid training while there is also a physician and a medical rescuer in the team. During an emergency operation, the rescuers use

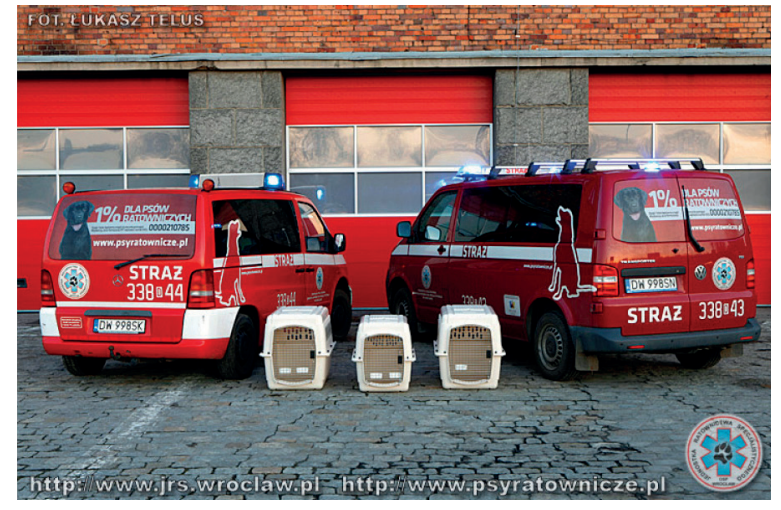

FIGURE 3. The equipment of VFDS SRU in Wroclaw

4 teams with tracking dogs and 2 teams with search and rescue dogs (Fig. 3). The VFDS SRU in Wroclaw was founded on 26th of June 2004 as the first unit of this type in Lower Silesia. On the 30th of March 2012, this unit was entered by the province into the registry of units cooperating with the NMR System. This unit has participated in 84 rescue operations. Moreover, rescuers of the VFDS SRU in Wroclaw provided certified first aid in 7 traffic accidents and regarding missing persons found during searching operations. The unit had also permanent duties during the EURO 2012 football championships.

\section{Medical Rescue Team Unit of the Polish Red Cross "Wroclaw"}

The Medical Rescue Team Unit of the "Wroclaw" Polish Red Cross (MRTU PRC "Wroclaw") is a rescue unit comprising a group of about 30 rescuers specialized in medical and specialist rescue, as well as many engineers and scientists. The aim of this group is to provide medical help to those in need and to support professional rescue teams during the rescue operations, especially during disasters and natural and structural catastrophes. The comprehensiveness of the specializations of the members of this team make it possible to provide technical and professional rescue operations in different situations and in different conditions. This is why this unit may carry out the following tasks:

- Directly at the site of the catastrophe: The rescuers are trained and appropriately equipped in order to carry out rescue operations in cooperation with professional teams, directly at the site of the catastrophe. They have appropriate personnel and lifesaving equipment and are prepared to rescue and evacuate those injured to a safe area;

- Camp dressing station / mobile medical point: MRTU PRC "Wroclaw" is the only volunteer res- 


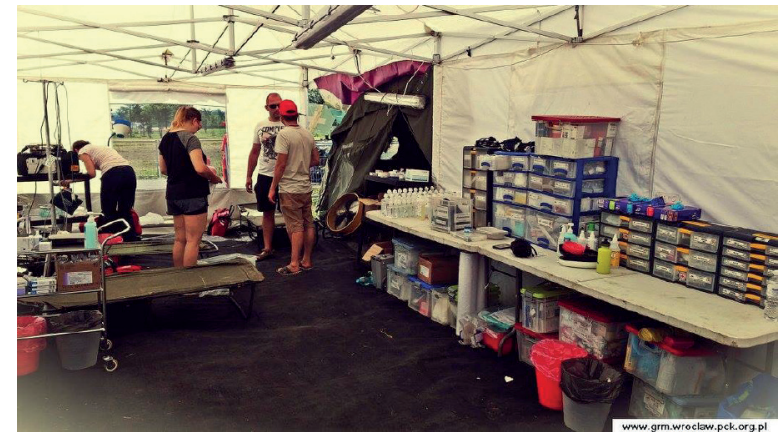

FIGURE 4. The camp hospital of MRTU PRC "Wroclaw"

cue unit in Poland capable of building a Camp Dressing Station providing 20 module beds, whose size may be adjusted to a particular situation and which can assure a long-lasting care to those injured. This ambulatory is adjusted to operate in camp conditions, may be quickly built and provides professional care to many injured persons (Fig. 4);

- Public assemblies and the safety of citizens: In order to provide medical care to the general populace during assemblies and public events (even the biggest in the country, with attendances of more than 100,000 participants) the rescue unit uses the benefits of the CDS (camp dressing station). MRTU PRC "Wroclaw" is formed by medical rescuers, scientists from the leading academies in Wroclaw, cavers and PRC rescuers. In accordance with the law regarding National Medical Rescue teams, the unit comprises 2 physicians, 17 medical rescuers and 11 persons who have completed certified medical rescue training. On the 8th of May, 2008, this group, as the first in Lower Silesia, was entered into the registry of units cooperating with the NMRS.

\section{The Volunteer Fire Department Service, "Starówka" ("Old Town") Specialist Rescue Group}

Scouts Rescue Team VFDS SSG "Starówka" was formally created in October 1998, and is the oldest unit of this type in Lower Silesia. The idea to create this group is related to the rescue operation which took place during the flood of 1997. This rescue unit has, from the very beginning, been involved in emergency operations. Over the years, the group underwent many changes, with VFDS SSG "Starówka" being finally instituted in 2013. The main aim of this unit is to operate and to join the rescue operations of the National Fire Department Service and the National

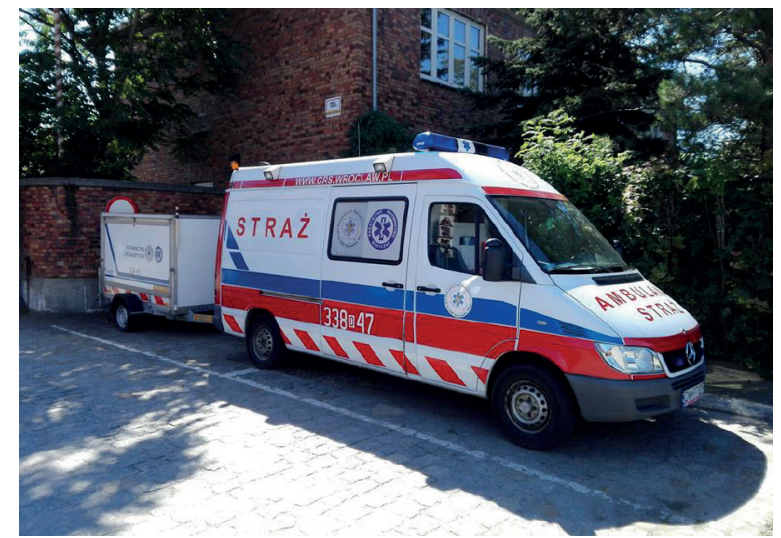

FIGURE 5. Ambulance of VFDS SSG "Starówka"

Medical Rescue Services. The unit should provide rescue teams experienced in medical rescue actions which can operate in the conditions in which the participation of the NMRT is not possible.

ntly, the unit has 35 members and candidates for members, 22 persons of whom possess a medical education (physicians, nurses, medical rescuers). There are also some rescuers who have completed a certified first aid training, firefighters from the NFDS, as well as engineers. The unit has a mobile first aid post which contains a full range of rescue equipment and an independent power and heating supply. This set-up is a part of a disaster kit based on a container-trailer which is part of the equipment of the unit. Moreover, the unit possesses a rescue car adapted to the transport of people, as well as an ambulance (Fig. 5). This unit has been cooperating for many years with professional formations working in Wroclaw and in the province of Lower Silesia. In 2010, this group was included in the rescue operation of the Provincial Headquarters of the NFDS which operated during the flood of that year. Many times the Provincial Executive Position of the NFDS and the Crisis Service Centre put the unit on increased readiness in order to secure the operational reserve during the crisis. VFDS SSG "Starówka" is one of a few units which possesses an agreement to permanently cooperate with the antiterrorist subdivisions of the police and to ensure medical help during high-risk operations. On the 26th of May 2014, the unit was entered by the province into the register of units cooperating with the NMRS System.

\section{The Volunteer Fire Department Service "Lazarus"}

This unit operates in Wroclaw and on the territory of Lower Silesia. It is a unique volunteer unit of volunteers in the province which focuses on medical rescue. 


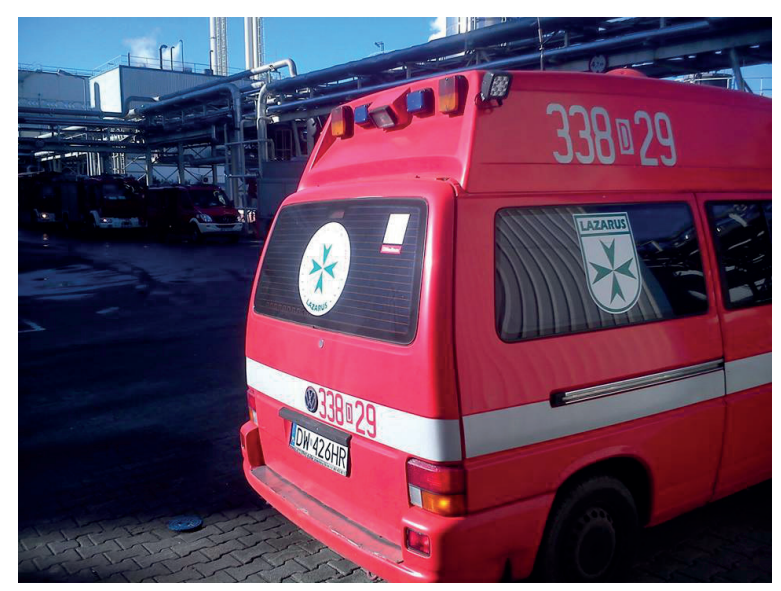

FIGURE 6. Ambulance of VFDS "Lazarus"

In this group there are physicians, medical rescuers and nurses, as well as rescuers who have completed certified first aid training.. The unit has two ambulances while the specialist equipment of this unit enables it to operate in places with high number of injured persons and to complement operations being carried out by the professional NMRT (Fig. 6). On the 21th of July 2010, this unit was entered by the province into the registry of units cooperating with the NMRS System [11].

\section{SUMMARY}

When estimating the potential risk of an important disaster on the territory of Wroclaw and Lower Silesia, we should divide the potential dangers into two groups. The first group, comprising natural dangers, includes flood and hurricanes The second, which involves a man-made factors, includes disasters involving traffic (roads, railways, aircraft), accidents in chemical manufacturing plants and large fires within industrial areas. The description of the volunteer organizations supporting the NMRS shows that the operation of these units is mostly focused on certified first aid and on the medical rescue operations within the secure area. Moreover, these units may be used during construction disasters to search and to evacuate people from the unsecured zone to CDS. The average time of reaching a disaster zone by the units supporting the NMRS System, according to the registry of the province of Lower Silesia, is a total 60 minutes. The presented data suggest that it is reasonable to dispose these units to long-lasting operations being conducted in an area of difficult territory. The equipment base shows that these units may support operations being undertaken by units of the professional services. Uniform regulations concerning the training and equip- ment have enabled the unification of these units, a factor which has subsequently allowed one to define clear criteria of where to dispose these units. The frequent training of volunteer organizations together with professional units allow one to align the operational procedures at a disaster site. Thus, the very high level of potential of the above-presented groups significantly improves the security of the inhabitants of Wroclaw and Lower Silesia.

Conflict of interest: None declared.

\section{REFERENCES}

1. Gawłowski P, Iskrzycki Ł, Smereka J. Zasady postępowania w przypadku akcji ratowniczej. In: Napierała M, Skaliy A, Żukow W. ed. Stan, perspektywy i rozwój ratownictwa, kultury fizycznej i sportu w XXI wieku. University of Economy, Bydgoszcz 2011.

2. Plan zarządzania kryzysowego Dolnośląskiego Urzędu Wojewódzkiego na rok 2016.

3. Gawłowski P, Iskrzycki Ł, Stępień P. Skuteczność prowadzenia akcji poszukiwawczych w trudnym terenie oraz działanie w zdarzeniach masowych przez ratowników na poziomie kwalifikowanej pierwszej pomocy. In: Horyń W, Wełyczko L. ed. Edukacja dla bezpieczeństwa w XXI wieku: człowiek - społeczeństwo - państwo. Wyższa Szkoła Oficerska Wojsk Lądowych im. gen. T. Kościuszki, Wrocław 2012.

4. Ustawa o Państwowym Ratownictwie Medycznym, Dz.U. $2006 \mathrm{nr}$ 191 poz. 1410.

5. Ustawa o bezpieczeństwie osób przebywających na obszarach wodnych, Dz.U. 2011 nr 208 poz. 1240.

6. Ustawa o bezpieczeństwie i ratownictwie w górach i na zorganizowanych terenach narciarskich, Dz.U. 2011 nr 208 poz. 1241.

7. Iskrzycki Ł, Zyśko D, Smereka J, Gawłoski P. Ratownik medyczny w strukturach ratownictwa wodnego. In: Konieczny J. ed. Ratownictwo medyczne: determinaty, analizy i rekomendacje. Garmond Oficyna Wydawnicza, Poznań 2014.

8. Zawadzki A. Medycyna katastrof. PZWL, Warszawa 2011.

9. Ładny JR. Zalecenia konsultanta krajowego w dziedzinie medycyny ratunkowej dotyczące procedur postępowania na wypadek wystąpienia zdarzenia mnogiego/masowego. Ministerstwo Zdrowia, Warszawa 2015.

10. Gawłowski P. Rola ratownika medycznego w świetle nowelizacji ustawy o Państwowym Ratownictwie Medycznym. Jednostki wspierające system PRM - niedoceniane ogniwo w systemie ochrony zdrowia. I Międzynarodowy Kongres Polskiego Towarzystwa Zdrowia Publicznego, Wrocław, 2015.

11. Gawłowski P, Zyśko D, Smereka J. Grupa ratownictwa medycznego PCK Wrocław jako przykład ważnego ogniwa w procesie szkolenia oraz organizacji akcji ratunkowych. In: Konieczny J. ed. Ratownik medyczny : problemy edukacyjne i organizacyjno-prawne. Garmond Oficyna Wydawnicza, Inowrocław - Poznań 2006. 